\title{
PENERAPAN TEKNIK KOLASE UNTUK MENINGKATKAN KREATIVITAS PADA KEGIATAN MENGGAMBAR PADA ANAK USIA DINI
}

\author{
Dedah Siti Jubaedah ${ }^{1}$, Rini Wulansari ${ }^{2}$, Ifat Fatimah Zahro ${ }^{3}$ \\ ${ }^{1}$ IKIP Siliwangi, JL Jenderal Sudirman Cimahi \\ ${ }^{2}$ IKIP Siliwangi, JL Jenderal Sudirman Cimahi \\ ${ }^{3}$ IKIP Siliwangi, JL Jenderal Sudirman Cimahi \\ 1dedahsitizubaedah@gmail.com, ${ }^{2}$ rwulansari045@gmail.com, \\ 3widiantara67@yahoo.com
}

\begin{abstract}
the application of the technique of collage to enhance creativity in early childhood learning to draw. This event will be based on research by the development of creativity in children is low with the emergence of several indicators that have not been developed. Initial observations showed the development of children's creativity has not been well developed. Rogers (Munandar: 2009:18) source of Creativity is an activity to develop potential in creating an idea or the idea of being more mature in order to express the ability of self. Creativity can improve a person's quality of life because of the creative people who can create new inventions. This research aims to find out (1) Conditions of social development of the students before the application of the technique of Collage (2) the results of the use of the application of the tekonik collage in enhancing creativity in early childhood learning to draw. The subject in this study was the son of Group B who are 5-6.
\end{abstract}

Key word: collage, creativity, early childhood

\begin{abstract}
Abstrak
Penerapan teknik kolase untuk meningkatkan kreativitas dalam pembelajaran anak usia dini untuk menggambar. Acara ini akan didasarkan pada penelitian dengan pengembangan kreativitas pada anak-anak yang rendah dengan munculnya beberapa indikator yang belum dikembangkan. Pengamatan awal menunjukkan perkembangan kreativitas anak belum berkembang dengan baik. Rogers (Munandar: 2009: 18) sumber Kreativitas adalah suatu kegiatan untuk mengembangkan potensi dalam menciptakan ide atau gagasan menjadi lebih matang untuk mengekspresikan kemampuan diri. Kreativitas dapat meningkatkan kualitas hidup seseorang karena orang-orang kreatif yang dapat menciptakan penemuan baru. Penelitian ini bertujuan untuk mengetahui (1) Kondisi perkembangan sosial siswa sebelum penerapan teknik Collage (2) hasil penggunaan aplikasi kolase tekonik dalam meningkatkan kreativitas dalam pembelajaran anak usia dini untuk menggambar. Subjek dalam penelitian ini adalah putra dari Grup B yang 5-6.
\end{abstract}

Kata Kunci: kolase, kreativitas, anak usia dini

How to Cite: Jubaedah, D.S., Wulansari, R., \& Zahro, I.F. (2018). PENERAPAN TEKNIK KOLASE UNTUK MENINGKATKAN KREATIVITAS PADA KEGIATAN MENGGAMBAR PADA ANAK USIA DINI. Ceria, 1 (3), 89-94. 


\section{PENDAHULUAN}

Masa kanak-kanak adalah masa pertumbuhan yang luar biasa,oleh sebab itu membutuhkan stimulus yang sesuai dengan keperluan anak agar perkembangan dan pertumbuhan anak tercapai secara maksimal. Peran pendidik, guru, dan orang tua sangat dibutuhkan dalam upaya pengembangan bakat yang dimiliki anak usia dini yang mana sangat penting dibutuhkan untuk menstimulus kebutuhan-kebutuhan anak dengan lebih anak baik dan menyiapkan dalam pendidikan selanjutnya.

Pertumbuhan dan perkembangan anak dapat berpengaruh pada kreativitas anak, jika anak dapat berkembang dengan baik maka anak dapat berkreativitas jauh lebih berkembang sesuai harapan.

Masa anak merupakan waktu belajar yang menakjubkan. Selain itu, kreativitas anak dimungkinkan akan berkembang dengan baik apabila lingkungan yang terdekat yaitu keluarga, rumah maupun sekolah turut memfasilitasi mereka dalam mengekspresikan kreativitasnya.

Kolase merupakan kegiatan yang mampu mengembangkan kemampuan kreativitas anak. Kolase adalah kegiatan anak yang berupa kegiatan menempel, dan merekatkan objek yang pada gambar yang telah disediakan. Adapun alat dan dalam pembuatan kolase, yaitu berupa kertas, yang digunting menjadi beberapa bagian. Kolase adalah kegiatan dalam seni rupa berupa menempel potongan-potongan kertas atau bahan alam lainnya.

Rogers (Munandar:2009:18) sumber dari Kreativitas merupakan kegiatan mengembangkan potensi diri dalam menciptakan suatu ide atau gagasan menjadi lebih matang agar dapat mengekspresikan kemampuan diri. Kreativitas dapat meningkatkan kualitas hidup seseorang karena orang-orang yang kreatif dapat menciptakan penemuan-penemuan baru.

PAUD Tarbiyatul Aulad adalah salah satu dari sekian banyak PAUD yang proses kegiatan pembelajarannya kurang terfokus pada pemanfaatan media pembelajaran dalam mengembangkan kreativitas anak. Berdasarkan observasi yang dilakukan pada saat pembelajaran menunjukkan bahwa kreativitas anak kelompok B masih belum berkembang sesuai harapan bila dibandingkan dengan kelompok lainnya. Dari hasil wawancara yang dilakukan peneliti dengan guru-guru di PAUD tersebut menyatakan bahwa kelompok B masih sangat kurang kreatif dalam menempel, belum mampu mengkombinasikan warna dalam membuat kolase dan anak belum mampu menghasilkan sesuatu yang baru dalam kegiatan kolase. Hal ini dapat terlihat ketika mengerjakan tugas yang berhubungan dengan keterampilan, khususnya membuat bentuk secara bebas dari kertas origami, anak belum percaya diri dalam membuat bentuk 
tempelan dan belum mampu mengkombinasikan warna.

\section{METODE PENELITIAN}

Metode dalam penelitian ini adalah metode Penelitian Tindakan Kelas (PTK). Dalam penelitian ini peneliti diposisikan bukan hanya untuk memecahkan masalah yang ada disalam kelas. Tetapi juga dapat merefleksikan suatu rencana pembelajaran.

\section{Melalui kegiatan observasi yang dilakukan di Kober Tarbiyatul Aulad Desa Ciharashas Kecamatan Cipeundeuy Kabupaten Bandung dapat diketahui bahwa kreativitas anak- anak di Kober Tarbiyatul Aulad masih sangat kurang dan belum berkembang dengan baik.}

\section{PEMBAHASAN}

Masa usia dini adalah masa yang sangat penting bagi anak karena pada masa itu anak akan mengalami perkembangan yang sangat menakjubkan pada semua aspek diantaranya aspek agama dan moral, kognitif, bahasa, fisik motorik, sosial emoasional dan seni.

Dari aspek agama dan moral dapat dikatakan bahwa pada masa anak usia dini anak akan mengenal perbuatan baik dan buruk juga mengenal Tuhannya dan agamanya. Pada aspek fisik motorik anak akan berkembang sel-sel otak dan organ-organ tubuh lainnya sehingga anak mampu berjalan, berlari, meloncat, memanajat dan sebagainya. Tak kalah penting juga dengan perkembangan aspek motorik halusnya anak akan berkembang kemampuan untuk mengkoordinasikan mata dan tangan, memegang sesuatu dengan kelima jarinya, menempel gambar, menulis hingga menggambar.

Pada aspek kognitif anak mulai mengenal pengetahuan umum, memahami persamaan dan perbedaan suatu gambar, mengenal bentuk, ukuran, pola dan warna juga akan mengenal konsep lambang bilangan dan huruf. pada masa anak usia dini aspek bahasa juga berkembang karena pada masa ini anak akan mulai berinteraksi dengan lingkungannya, anak mampu mengutarakan perasaaanya, menceritakan kembali apa yang dilihat dan dialaminya, dan mampu menjawab pertanyaan- pertanyaan yang sederhana maupun yang lebih kompleks.

Aspek sosial emosional juga akan berkembang dimana dalam usia ini anak akan mulai menunjukkan rasa percaya diri dan kemandiriannya, anak akan belajar bagaimana mengharga orang lain/ temannya, mulai berbagi dan menolong temannya dan anak akan mulai dapat mengendalikan perasaannya. Perkembangan juga ditunjukkan pada aspek seni. Anak akan mengekspresikan diri ketika mendengar sebuah lagu, dapat menggambar objek disekitarnya, dapat mengkombinasikan warna ketika mewarnai, dsb. 


\section{JURNAL CERIA}

ISSN : 2614-6347 (Print) 2614-4107 (Online)

Vol.1 | No.3 | Mei 2018

Kreativitas merupakan kemampuan seseorang untuk melahirkan suatu ide dan gagasan yang baru sehingga dapat menghasilkan suatu karya. Kreativitas untuk anak usia dini sangatlah penting agar anak siap menghadapi berbagai tantangan dimasa dewasanya nanti dan juga melalui kreativitas anak akan dapat mengekspresikan dirinya

\section{HASIL PENELITIAN}

Penelitian ini diawali dengan observasi awal peneliti dengan guru Kober Tarbiyatul Aulad pada hari Senin, 9 April 2018 pada Tahun Ajaran 2017-2018. Hasil observasi yang ditemukan dilapangan adalah masih rendahnya kemamapuan kreativitas anak. Pada saat kegiatan anak belum mampu mengahsilkan sesuatu yang baru. Sebelum dilakukan tindakan pada siklus I, terlebih dahulu anak kelompok B diberi tes awal untuk mengetahui kreativitas yang mereka miliki. Hasil tes awal menunjukkan kemampuan anak rata-rata masih belum berkembang. Tentu hal ini mengharuskan perlu adanya suatu tindakan dalam pengembangan kreativitas. Berdasarkan observasi pelaksanaan pengembangan kreativitas untuk siklus I, menunjukkan bahwa pengembangan kreativitas melalui kegiatan pembuatan kolase belum sempurna dilaksanakan sesuai dengan pembelajaran yang telah disusun dan disepakati anatara peneliti dan guru. Guru tidak menyampaikan tujuan pembelajaran yang akan dicapai dan kurang memberikan motivasi kepada anak. Selanjutnya, peneliti mencatat bahwa pada pertemuan pertama siklus I guru belum bisa mengorganisasikan waktu dengan baik sehingga sebagian inti pembelajaran tidak terlaksana. Selain itu ada beberapa langkah pembelajaran yang tercantum dalam RKH yang tidak dilakukan guru dalam kegiatan inti.

Disisi lain guru kurang mengontrol kegiatan anak secara menyeluruh, anak banyak yang terabaikan. Selanjutnya guru juga kurang memberikan arahan dan bimbingan, akibatnya banyak anak yang masih tidak fokus menyimak apa yang guru sampaikan. Diakhir pembelajaran, kegiatan penutup yang dilaksanakan hanya sebatas merangkum hasil pembahasan namuntidak melakukan refleksi bersama anak.

Padahal dengan refleksi anak dapat mengetahui apa yang perlu dilakukan dan apa yang tidak perlu dilakukan. Dalam perkembangannya keterampilan guru dalam mengembangkan kretivitas anak melalui kegiatan kolase semakin baik dari setiap pertemuan yang dilaksanakan. Pada pertemuan ketiga siklus I guru sudah memberikan penghargaan berupa pujian dengan ungkapan "bagus" bagi anak yang menyelesaikan kolasenya. Dalam pembelajaran ini juga peneliti mengamati perkembangan anak. Secara umum untuk siklus I terdapat beberapa kekurangan yaitu tidak semua anak aktif dalam belajar dan masih ada anak yang asyik dengan kegiatannya sendiri. Adapun kekurangan lainnya yaitu anak masih kurang berantusias dalam pembuatan kolase. 
Hasil tes tindakan siklus I menunjukan bahwa peningkatan kreativitas secara klasikal hanya 9 anak yang mulai berkembang. Hasil evaluasi yang diperoleh anak diatas belum mencapai indikator kinerja yang ditetapkan. Ada beberapa item yang peneliti anggap sebagai sebab tidak tercapainya hasil yang diinginkanbahwa pada siklus ini ada beberapa poin yang kurang maksimal atau bahkan tidak dilakukan oleh guru. Berdasarkan hasil observasi pada pelaksanaan tindakan untuk siklus II, peneliti memiliki beberapa catatan penting untuk pembahasan ini.

Kegiatan kolase pada siklus II ini cukup meningkat dari sebelumnya. Guru harus lebih menstimulus anak yang ditemui dalam dalam pelaksanaan tindakan siklus I. guru sudah mampu mengontrol kegiatan anak dikelas dengan cukup baik.

Guru telah memperbaiki kekurangan yang ditemui pada tindakan sebelumnya, dan anak juga turut aaktif dalam pembelajaran di kelas. Kekurangan guru yang masih banyak terjadi adalah masih kurang menyeluruhnya menstimulus kepada masing-masing anak.

Hal ini karena guru sudah mampu mengorganisasikan waktu pembelajaran dengan baik. Guru sudah cukup baik dalam memberi apersepsi kepada anak. Selanjutnya guru sudah mampu mengikuti langkah-langkah pembelajaran yang terdapat dalam RKH. Sementara itu, hasil observasi terhadap anak secara umum menunjukkan bahwa anak lebih antusias dan lebih aktif dalam pengembangan kreativitas.

Berdasarkan hasil observasi peneliti, dalam pelaksanaan observasi oleh guru pada siklus II telah mencapai indikator yang ditentukan, maka dari segi evaluasi anak sudah mencapai indikator kinerja yang ditetapkan.

\section{KESIMPULAN}

Berdasarkan hasil penelitian tentang meningkatkan kreativitas pada kelompok B di Kober Tarbiyatul Aulad melalui teknik kolase dapat disimpulkan bahwa peningkatan kemampuan kreativitas anak dengan menggunakan teknik kolase mengalami peningkatan yang sangat signifikan, hal ini terlihat bahwa anak sudah dapat menunjukkan perkembangan dengan hasil karya yang imajinatif sesuai dengan gagasan anak.

\section{DAFTAR PUSTAKA}

Munandar, U (2009). Pengembangan kreativitas anak berbakat. Jakarta: Rineka Cipta

Muharrar, S (2013). Kreasi kolase, montase, mozaik sederhana.Erlangga

Hendriana, H (2014). Panduan bagi guru Penelitian Tindakan Kelas Suatu karya tulis ilmiah. Bandung: Refika Aditama

Rachmawati, Y., \& Kurniati, E. (2011). Strategi pengembangan kreativitas pada anak. Jakarta : Kencana 


\section{JURNAL CERIA}

ISSN : 2614-6347 (Print) 2614-4107 (Online)

Vol.1 | No.3 | Mei 2018

Mursid. 2015. Belajar dan Pembelajaran PAUD.

Bandung: PT Remaja Rosdakarya

Madiarti, E., Kurnia, N., \& Sholihah, A. (2013). Peningkatkan

Keтатрuan

Motorik Halus Anak Melalui Kegiatan

Kolase Dengan Menggunakan Media
Berbantuan Bahan Alam di Paud Melati Kabupaten Lebong (Doctoral dissertation,

Universitas Bengkulu). 